\title{
Response of Carob Tree to Nitrogen Fertilization
}

J. Lloveras ${ }^{1}$ and J. Tous

Institut de Recerca i Tecnologia Agroalimentàries, Centre de Mas Bové, Apartat 415, 43280 Reus, Spain

Additional index words. Ceratonia siliqua, nutrition

The carob (Ceratonia siliqua L.), a leguminous fruit tree that is unable to fix $\mathrm{N}$ (Martins-Louçao, 1985), is commonly grown in Mediterranean coastal areas. In the last 5 to 10 years, because of the rising prices of locust bean gum (LBG), a derivative of carob seeds, the carob has been the object of renewed interest (Esbenshade, 1987; Johnsen et al., 1987; Spina, 1986; Tous and Batlle, 1990). However, this recently renewed commercial interest has not been associated with any improvement in agricultural production practices because of the limited information available, particularly on fertilization. Normally, fertilizer is not applied (Orphanos, 1980; Spina, 1986; Tous and Batlle, 1990; Winer, 1980).

The objective of this work was to determine the response of carob pod production to $\mathrm{N}$ fertilization.

Field trials were conducted under nonirrigated conditions in Reus during 1987 to 1989. Annual rainfall during the experiment was 625,329 , and $670 \mathrm{~mm}$ in 1987, 1988, and 1989 , respectively. Five plots, $\approx 3000$ $\mathrm{m}^{2}$ and separated from each other by 100 to $200 \mathrm{~m}$, were selected for the experiment. In four of the plots, trees were 35 years old with an average height of $5 \mathrm{~m}$ and a canopy diameter of 4 to $5 \mathrm{~m}$, while those on the fifth plot were $>50$ years old and taller than $6 \mathrm{~m}$ with a canopy diameter of $\approx 5$ to $6 \mathrm{~m}$. The plant spacing was $\approx 15 \times 15 \mathrm{~m}$ (45 trees/ ha).

Soil type was Petrocalcic Xerochrept. The main soil characteristics were: $\mathrm{pH}$ of 7.8 , organic matter content between 6 and 17.2 $\mathrm{g} \cdot \mathrm{kg}^{-1}$, available $\mathrm{P}$ from 2.5 to $4.9 \mathrm{mg} \cdot \mathrm{kg}^{-1}$

Received for publication 26 June 1991. Accepted for publication 23 Jan. 1992. We thank L. Torres, X. Flotats, and I. Romagosa for their statistical assistance. The cost of publishing this paper was defrayed in part by the payment of page charges. Under postal regulations, this paper therefore must be hereby marked advertisement solely to indicate this fact.

'Current address: UPC-IRTA, Rovira Roure 177, Lerida 25006, Spain.
(Olsen method), available $\mathrm{K}\left(\mathrm{NH}_{4} \mathrm{Ac}\right)$ between 32 and $266 \mathrm{mg} \cdot \mathrm{kg}^{-1}$, and $\mathrm{CaCO}_{3}$ equivalent from 240 to $739 \mathrm{~g} \cdot \mathrm{kg}^{-1}$.

In each of the five chosen plots, the five most uniform trees ('Rojal') were selected and used as experimental units (these trees were separated by at least one border tree). Five rates of fertilization $(0,40,80,120$, or $240 \mathrm{~kg} \cdot \mathrm{ha}^{-1}$ ), corresponding to $0,0.9,1.8$, 2.7 , and $5.4 \mathrm{~kg} /$ tree, were applied annually. Of these quantities, $0.4 \mathrm{~kg} / \mathrm{tree}\left(20 \mathrm{~kg} \cdot \mathrm{ha}^{-1}\right)$ was broadcast around the trees in November, except for the trees in the highest $\mathrm{N}$ treatment $\left(240 \mathrm{~kg} \cdot \mathrm{ha}^{-1}\right)$, which received $0.9 \mathrm{~kg} /$ tree, and those that received no fertilizer $\mathrm{N}$. The rest of $\mathrm{N}$ was broadcast at the end of February. In the fall, all trees received an annual basal fertilization consisting of $44 \mathrm{~kg}$ $\mathrm{P} / \mathrm{ha}$ and $125 \mathrm{~kg} \mathrm{~K} / \mathrm{ha}$.

Pods from each selected tree were harvested by hand in October and weighed separately. The mean pod yield of five plots for each rate of $\mathrm{N}$ were used to calculate the best fit equation $\left(\right.$ yield $=82.6+0.174 \mathrm{~N} ; R^{2}$ $=0.81 ; P<0.05)$.

Carob production increased with increasing $\mathrm{N}$ fertilization levels. The slope of the

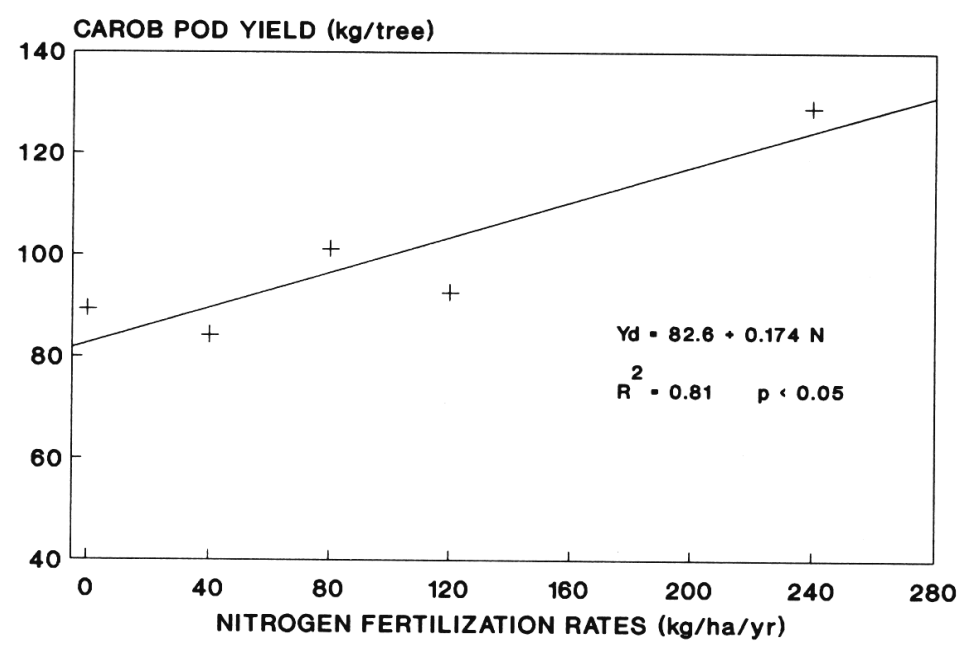

Fig. 1. Carob pod yield (Yd) response to five N fertilization rates. Average for 1988 and 1989. regression line and the pod yield reached by some trees $(184 \mathrm{~kg} /$ tree $)$ leads us to believe that the highest production potential was not yet reached with the $\mathrm{N}$ rates we applied.

The relatively high yields of the unfertilized trees might be partially due to the application of $\mathrm{P}$ and $\mathrm{K}$ fertilizer. If no $\mathrm{P}$ and $\mathrm{K}$ fertilization had been applied, which is the normal practice, average yields might have been lower because of the low $\mathrm{P}$ and $\mathrm{K}$ contents in the soil.

The experiment shows that carob trees respond to $\mathrm{N}$ fertilization by increasing pod yield, at least up to $240 \mathrm{~kg} \mathrm{~N} / \mathrm{ha}$, although the biannual production characteristic of the species and the irregular Mediterranean weather pattern make prediction of the response difficult.

\section{Literature Cited}

Esbenshade, H.W. 1987. Carob: International distribution and production potential. Proc. II Intl. Carob Symp. Valencia, Spain. p. 303-316.

Johnsen, S., P. Bruun, and P. Okkala. 1987. Application of L.B.G. in food and pet food systems. Proc. II Intl. Carob Symp. Valencia, Spain. p. $577-587$.

Martins-Louçao, M.A. 1985. Estudos fisiol6gicos e microbiológicos da associaçao da alfarrobeira (Ceratonia siliqua L.) com bacterias de Rhizobiacease. PhD Diss., Univ. de Lisboa. Portugal.

Orphanos, P.I. 1980. Practical aspects of carob cultivation in Cyprus. Portugal Acta Biol. (A) XVI (1-4):221-228.

Spina, P. 1986. I1 carrubo. Edagricole. Bologna, Italy.

Tous, J. and I. Batlle. 1990. El algarrobo. MundiPrensa. Madrid, Spain.

Winer, N. 1980. The potential of carob (Ceratonia siliqua L.) Intl. Tree Crops J. 1:15-26. 